\title{
Tensions in the New Millennium: Inclusion Ideology and Education Policy in the Finnish Comprehensive School
}

\author{
Juha T. Hakala ${ }^{1} \&$ Marjaana Leivo ${ }^{1}$ \\ ${ }^{1}$ University of Jyväskylä, Jyväskylä, Finland \\ Correspondence: Juha T. Hakala, University of Jyväskylä, Jyväskylä, Finland. E-mail: juha.hakala@chydenius.fi
}

Received: April 11, 2017

Accepted: April 29, 2017

Online Published: May 9, 2017

doi:10.5539/jel.v6n3p287

URL: http://doi.org/10.5539/jel.v6n3p287

\begin{abstract}
This article examines the discrepancy between the ideology of inclusive education and the national education policy in the Finnish comprehensive school education. The study covers twenty years and is based on observations that indicate that the change in comprehensive school education, grounded in inclusive education ideals, has been slow. This has been the case, even though Finnish education policy has, on principle, committed to many international statements that promote inclusion ideology. The data consists primarily of statistics indicating the number of students in special education and national and international research on the subject. It confirms our supposition, but also the fact that statistics are not merely challenging but also capable of distorting reality. While examining the changes in student quantities over the last twenty years, we came to the conclusion that the fluctuation does not result from any real growth in student numbers. Changes in statistical methods, terminology in the field of study, norms, education systems or even social phenomena can also cause distortion.
\end{abstract}

Keywords: comprehensive school, education policy, inclusion, inclusive education, schools' culture, special education

\section{Context, Concepts and Objectives}

The United Nations adopted the Standard Rules on the Equalization of Opportunities for Persons with Disabilities in 1993. One of its goals was to achieve fully integrated education in all UN countries. The following year, UNESCO organized an international conference where governments from 90 countries signed the so called Salamanca Declaration (1994). It is an education policy program that introduced, specified and individualised the concepts of inclusion and the inclusive school for the first time. According to the declaration (UNESCO, 1994, pp. 5-14), both integration and inclusion should be advanced in a way that emphasises communal, rather than individual requirements. Respectively, instead of focusing on disability, which had been the case for a long time, societies should finally start focusing on strengths. As stated in the declaration, school is a place where children with special educational needs could study in regular classrooms instead of special classes. Hence, inclusion was no longer merely defined in relation to pupils with special educational needs, it now called for a much more thorough adjustment in the schools' operational culture (Also Mietola \& Niemi, 2014).

The Salamanca Declaration was followed by the UN Convention on the Rights of Persons with Disabilities in 2006 (UN, 2014). The convention aimed at inhibiting all discrimination based on disability (Moberg \& Savolainen, 2015, p. 89). Due to these documents, and others, developing education for all pupils, based on the broad conceptualisation of inclusivity (Booth \& Ainscow, 2002; Waitoller \& Artiles, 2013), became the general objective of inclusive education ideology. As a result of the Salamanca Declaration and other international programmes and agreements, Finland along with other Western Nations, committed to reforming its educational system towards a more inclusive model (Ministry of Education and Culture, 2007).

When one takes a look at the documents that have guided Finnish education in the last decade, one gets the impression that schools have indeed embraced the principles of inclusive education. It is apparent in the strategic work that steers special education in the Finnish comprehensive school education (Ministry of Education and Culture, 2007), in the constitutional amendment concerning assistance in education and learning that became effective in the year 2011 (Laki perusopetuslain muuttamisesta, 2010), in the new pupil welfare law (Oppilas-ja opiskelijahuoltolaki, 2013) and in the rationalization of the 2014 curriculum reform (Finnish National Board of Education, 2014). Despite all this supporting evidence, some of the research and statistical documents indicate that in practice the Finnish education system has in fact been slow to change to a more inclusive form. Many of the 
current pedagogic guidelines and norms governing the Finnish school system entail an idea of a profile for "an inclusive teacher" (European Agency for Development in Special Needs Education, 2012) but the reality does not necessarily reflect that. For instance, small groups and special classes are still quite common (e.g., Thuneberg \& Vainikainen, 2015). In other words, discriminating structures have diminished on an ideological level (e.g., Isosomppi \& Leivo, 2015), but segregating, exclusive institutions, i.e., special schools and classes, still exist (Moberg \& Savolainen, 2015, p. 81; see also Mietola, 2014). Moreover, there are still relatively few schools where pupils learn in shared groups.

In this article, we will contemplate issues from a historical and a conceptual standpoint: why has the transformation to inclusive education been so slow? What changes have we observed in the organisation of the Finnish basic education from an inclusive viewpoint between the middle of the 1990's and 2015? Finally, in the light of the above questions, we will ponder the possible future challenges while developing the Finnish school into a more inclusive one.

We will define our own relationship with the core concepts of inclusive pedagogy before the actual review. We see inclusive, participatory teaching as an educational experience for the whole generation: no one is excluded due to a disability or any other quality (see Ladonlahti \& Naukkarinen, 2006; Waitoller \& Kozleski, 2013). Inclusion and integration are usually presented in pedagogic literature as comparable concepts because both place pupils in need of assistance in regular groups (Viitala, 2004, pp. 132-133). When we talk about integration in this article, we refer to measures that place pupils with special educational needs temporarily or permanently in mainstream education (see e.g., Emanuelsson, 2001; Farrel, 2001; Naukkarinen, 2000). In an ideal situation, integration processes aim at or can lead to inclusion. Today, integration, as a term that depicts physical repositioning of individuals, has been partly abandoned because it might be understood as stigmatizing or medicalising (e.g., Saari, 2011, p. 15, p. 20). Moreover, so called broad concept of inclusion entails more than just pupils with learning disabilities, it also refers to inclusions and exclusions base on gender, culture and a social status (Waitoller \& Artiles, 2013; Isosomppi \& Leivo, 2015).

We wrote this article well aware of the fact that the terminology of inclusive pedagogy is not unambiguous. A relative consensus on the values behind inclusive teaching (i.e., equity and participation) exists on an international level but there has been variation in how these values should be put into practice in everyday school work. Particularly the term "full inclusion", divides researchers (Malinen et al., 2009, p. 352). In this article, we assume that the development of inclusive education is a process (Booth \& Ainscow, 2002; McMaster, 2014). Partly for this reason, the connotations attached to concepts of inclusion are always linked to a particular context, culture, time and a place (also Ainscow \& César, 2006).

\subsection{Existing Norms Prove Caution in Inclusion Policy}

When Finland committed to the Salamanca Declaration in the middle of 1990s, the educational authorities had to seriously contemplate their relationship with inclusion. Finally, the educational administration's reaction to the declaration was hesitant. Special education Professor Timo Saloviita (2006) from the University of Jyväskylä teacher training interpreted it as containing evasive characteristics. Nonetheless, in the turn of the millennium, expressions characteristic to inclusive education found their way to essential education policy agendas albeit in moderate form. For example, the Finnish comprehensive school curriculum criteria from 2004 stated that "if a pupil is, for any reason, unable to take part in mainstream education or doing so is not otherwise expedient, education should be partly or wholly arranged in special education groups" (Finnish National Board of Education, 2004, p. 29). This inspired Saloviita (2006, p. 355) to conclude that based on the vagueness of the statement, schools were free to determine individual pupils' interests in special education transfers themselves. In practice, the broad interpretation of curriculum made it possible for the educational professionals to completely abandon integration. Schools could make vastly different choices in integration cases and still properly follow the official guidelines.

Furthermore, one is hard pressed to find indications of the inclusion principles, adopted in the new millennium, in the government's education and research development plans. Notably, the education and research development plan (2007-2012) of the second government of the former Prime Minister Matti Vanhanen (Centre Party), did not mention the concept of inclusion at all; it did not even include the general objective of developing a more inclusive school. The aforementioned government's development plan contains plenty of expressions that can implicitly be understood to refer to separate special education classes and schools but also to the most common inclusive education principles. Perhaps, the greatest achievement of said government in the area of education policy, was the renewal of special education to include an educational support system (Lintuvuori, 2015; Ahtiainen, 2015). Likewise, the following government, led by Jyrki Katainen from the National Coalition Party, did not include the 
concept of inclusion in their education and research development plan for the years 2011-2016. Instead, the document does contain a more implicit idea of developing an inclusive school: "Basic education will be developed in such a way that it is shared by the whole generation, education should ensure equal preconditions to all. Desegregation of schools will be prevented and existing differences ironed out" (Education and Research, 2011-2016, pp. 25-26).

We have written this article with the assumption that the educational approach, drafted by the political elite, can eventually be discerned from the official educational guidelines and agendas. This holds true in Finland with one discrepancy: the norms governing actual schools are relatively adamant when it comes to inclusivity specifically. However, there is an explanation for this. Retrospectively, the Special Education Strategy in 2007 (Ministry of Education and Culture, 2007) formed as a solution to global pressure for inclusion (e.g., UNESCO, 1994). On the other hand, it aspired to solve the nationally unsustainable and statistically factual issue of vastly increased amount of pupils in special education (e.g., Lintuvuori, 2015). The purpose of the strategy was clearly to demolish the dual structure that had been in place for decades, and further, to develop education in general. According to the special education strategy (Ministry of Education and Culture, 2007): "all teaching should take place in mainstream education if possible". This special education strategy, currently in force, emphasises the so called neighbourhood school principle according to which "teaching heterogeneous groups is the responsibility of all teachers" (Ministry of Education and Culture, 2007, p. 21).

The definition of diversity the early 2000s, evident in the Finnish school administration's documents, can be described as a slow process as available services determined "difference" and the subsequent pedagogical solutions. However, due to the Amendment of the Basic Education Act in 2010 (Basic Education Act, 2010, p. 642; OPM, 2007), the school administration shifted to the so called Three-Tier Support Model, i.e., general, intensified and special support. In practise, special education was now able to redefine its own place in the Finnish comprehensive school system (Hautamäki \& Hilasvuori, 2015). The primary aim was to give pupils general support, in the form of remedial teaching or part-time special education. After that, pupils would receive intensified education if necessary. Special support was to be the last alternative. In brief, despite the fact that the three-tier model, in use in Finnish comprehensive schools, cannot be considered a direct implementation of the inclusion ideology, it was clearly an indication of a new framework for the language and practise of special education.

It is noteworthy, and significant for the future of inclusive education, that the concept of inclusion is not explained in any specific way in the principles of the new curriculum effective in Finnish schools in August 2016 (Finnish National Board of Education, 2014). Developing the school, according to the "principles of inclusion" is stated as an objective (Finnish National Board of Education, 2014, p. 18), but the new curriculum offers a lot of freedom in realizing this goal. When it comes to inclusive pedagogy, the curriculum is not very definite. The guiding principles of the curriculum (Finnish National Board of Education, 2014) do refer to the central aspirations of inclusive ideology, like preventing inequality, marginalization and equal treatment between genders, but the tangible methods and the degree of concrete action are still to be defined by the implementer. Salminen and Annevirta $(2014$, p. 344) drew similar conclusions when they reviewed the principles underlying the basic education curriculum of 2004 and its 2010 amendments and attachments. Their analysis indicates that the teaching guidelines conveyed by these documents, are quite lax and focused mainly on describing the three-tier model of pupil support giving teaching and learning theories, as well as explicit guidance, little attention.

\subsubsection{The Dual System Hindered Inclusive Thinking}

Strong attitudes have cast a pall over the adoption of inclusive school education in Finland. Those attitudes have their origins in the history of the nation's s education system. Like many other countries, the Finnish education system has for decades followed a dual system in which the special education and mainstream education are seen as separate functions (e.g., Ainscow \& César, 2006, p. 232; Ainscow, Dyson, \& Weiner, 2014; Meijer, 2010). The dual system categorized pupils into normal or abnormal, into mainstream education or special education based on medicalization and accentuating medical diagnosis (Seppälä-Pänkäläinen, 2009, pp. 14-15). According to Kivirauma (2015), special education and the concept of difference have always been shaped by the viewpoints of the school system and the individuals who work in it. Furthermore, the relationship between "different" and "normal" influences special education. When we review the dual system, it is important to remember that the relationship is culturally defined. It is also time and place specific. For instance, pupils that were regarded as normal in the mid 1900's in the previous comprehensive school system would have been steered to special education in the early 2000s (Kivirauma, 2015, p. 16.) This statement undoubtedly holds true in all the countries that adhered to the dual system. 
Finland has, for decades, rationalized the existence of the dual system by its emphasis on pupil's individual needs. Special education, organized within the system, appeared as a positive way to implement educational equality. Based on this view, special education has mainly been understood as a pupil's right to special learning support (e.g., Järvinen \& Jahnukainen, 2008; Mietola \& Niemi, 2014). On the other hand, alternative views have been presented. Special education has also been seen as a tool for selection and segregation within the education system. It has been viewed as a stigmatizing practise that highlights abnormality (see Niemi, 2014). The fact of the matter is that due to its long reign, the dual system is deeply engrained in pupils', parents' and teachers' thinking and they have largely accepted it as part of the existing educational culture. We claim that this attitudinal connection has been so strong and rooted so deep that the dual system still influences, not only municipal schools, but also educational administration, teacher training and the research community; it guides their action and hinders the adoption of inclusive ideology.

Over the past few decades, the operating culture and the laws guiding basic education in Finland, have seen some changes aimed at dissolving the dual system. While reviewing this process we should note that the UN and UNESCO-led integration policy alignment, took place during the implementation of the new Finnish comprehensive school curriculum (1994). At the time, the current comprehensive school ideology emphasised "accepting difference in class" referring to the organisation of special education according to the principle of normalization (Mietola \& Niemi, 2014). School practice revealed that the objective of inclusion remained merely an aspiration that the comprehensive school strived for but could not attain in the new curriculum.

In hindsight, the 1994 curriculum reform can be seen as indicative of the fact that inclusive thinking is not easily assimilated in the Finnish comprehensive school. One clear reason for the slow start on inclusive pedagogy is that it was not until the late 1990s that the whole generation (all the different learners) studied in the same comprehensive school system. At the same time, extensive changes were made in the social and health care administration. At that time, the most severely mentally handicapped pupils were transferred from under the social and health sector to the education sector (Jahnukainen, 2003, p. 501). Jahnukainen (2015, p. 7) mentions two subsequent, significant changes related to inclusive thinking. First, the government discontinued the so-called "increased state subsidy" in the beginning of 2010. Before, municipalities received increased funding for pupils with special educational needs, or more precisely, for those who were placed or transferred into special education (Act on Central Government Transfers to Local Governments for Basic Public Services 1704/2009). It was replaced by a population-based value (6 to 15 year olds in the municipality), an attempt to take special educational needs into account on a municipal level (Pulkkinen \& Jahnukainen, 2015, pp. 79-80). Second, the dual system was transformed into a learning and school support system, which meant that all Finnish schools started to apply the so-called three-tier support system. Alongside these changes, the slowness in the assimilation of educational concepts was perceptible.

The concepts of integration and inclusion, not to mention inclusive ideology, did not advance beyond upper levels of school administration. A fact that undoubtedly hindered the commitment to inclusion. The terms were mentioned in school administration's documents but teachers and principals rarely became aware of them or their true sense. For instance, Finnish schools started to officially use the term integration in the 1990's (Saloviita, 2012), but it did not directly describe the aspiration to diminish special education in separate classes or schools. This contradiction is merely an example and its relevance becomes clearer when we return to the present day. Indeed, interpretations of the concept of inclusion vary (see Malinen et al., 2009) among the international research community even today (e.g., Ainscow, Dyson, \& Weiner, 2014). According to Mietola and Niemi (2014, p. 69), differences between interpretations can be associated, for instance, with the significance of the neighbourhood school policy to the advancement of inclusion and the position of the special schools is in this development (Meijer, 2010). Different, negative impressions related to the concept of "special" seem to prevail despite the fact that the Finnish school system has attempted to shed that stigmatising conceptualisation (Mietola, 2014).

\section{Statistics and Their Problematic Interpretation}

Statistics related to special education in the Finnish comprehensive school seem to support the above described developments until the year 2010. However, interpretation can be very difficult due to changes in classification criteria. Particularly, there were very few pupils attending special education in Finland before the 1950s, less than 3000 in fact. Statistical analysis was easier then as special education typically took place in separate classes and schools. Retrospectively, the comprehensive school reform that became effective in 1970, and the expansion of part-time special needs education, were the real culprits of statistical fluctuation. These developments caused the amount of pupils in special education to grow exponentially (Kivirauma, 2001; Jahnukainen, 2003), and this was eventually reflected in the statistics. For instance, between 1995 and 2010, the amount of pupils in special 
education almost tripled from less than three percent to 8.5 percent. The number of pupils in separate classrooms was roughly six percent, the rest received their education in regular classes. In other words, 46,700 of over half a million pupils received special education in the autumn of 2010 (Statistics Finland: Special education, 2010).

Current statistics measure the amount of pupils receiving intensified and special support instead of pupils in special education. Consequently, the statistics change and comparison to previous years becomes even more difficult than it already is. For example, between 1995 and 2010 pupils "in" or "transferred to" special education referred to pupils placed or moved there due to a disability, illness, delayed development, an emotional disorder or for some other reason. Placement and transfer decisions were made by a municipal body. The decision required the consultation of experts and parents alike and the formulation of a plan for individualized education (Statistics Finland: Special education, 2010). In 2011, statistics measuring support in learning and school attendance had to be reassessed so that they would better reflect the legislative changes in basic education as well as the curriculum changes and supplements of 2010. Emphasis in compiling statistics changed from measuring the reasons pupils receive support to describing the support offered by the system. Categorisation based on diagnostics was abandoned mainly due to the renewal of the Finnish Basic Education Act. The new law emphasised pedagogical values and expertise over medical expertise (Lintuvuori, 2015).

From an inclusive point of view, positive changes started to emerge after the special education legislation amendment in 2011. Namely, the share of pupils receiving special support started to reduce (Lintuvuori, 2015, p. 52). Actually, this occurred because comprehensive school pupils that had been placed or transferred to special education were now compared to pupils receiving special support. For inclusion analysis, this development was not unproblematic as the total percentage of pupils receiving learning support was still on the rise. An interesting statistical occurrence explained by the fact that pupils receiving "intensified" and "special support" -as per new terminology- were now grouped together. One of the most striking characteristic of national development was that the share of pupils receiving learning support ranged in this large but sparsely populated country, not only regionally but also in gender distribution (Heiskala, 2014). However, Lintuvuori $(2015$, p. 50) remarks, that the growth in statistics was not always indicative of growth in pupil numbers. These changes could have resulted from the new measurement scales, as well as from the new financing system or the updated laws, the three-tier support system that became effective in 2010 and particularly, the related redefinition of evaluation and monitoring tools but also from lack of timely support (Pulkkinen \& Jahnukainen, 2015, p. 81).

Table 1. Comprehensive school pupils receiving intensified or special support in 2014 (Statistics Finland: Special Education 2014)

\begin{tabular}{|c|c|c|c|c|c|c|c|}
\hline \multirow[b]{2}{*}{ Grades/Gender } & \multicolumn{2}{|c|}{$\begin{array}{l}\text { Students who recieved } \\
\text { enhanced support }\end{array}$} & \multicolumn{2}{|c|}{$\begin{array}{l}\text { Students who recieved } \\
\text { special education }\end{array}$} & \multicolumn{2}{|c|}{$\begin{array}{l}\text { Students who recieved enhanced } \\
\text { support and special education }\end{array}$} & \multirow[b]{2}{*}{$\begin{array}{l}\text { Ammount of } \\
\text { students in the } \\
\text { school }\end{array}$} \\
\hline & Altogether & $\begin{array}{l}\text { Percentage of } \\
\text { the schools } \\
\text { students, \% }\end{array}$ & Altogether & $\begin{array}{l}\text { Percentage of } \\
\text { the schools } \\
\text { students, \% }\end{array}$ & Altogether & $\begin{array}{l}\text { Percentage of the } \\
\text { schools } \\
\text { stundents, \% }\end{array}$ & \\
\hline Preschool education & 187 & 1,6 & 918 & 8,0 & 1105 & 9,7 & 11424 \\
\hline Grades 1-6 & 27573 & 7,8 & 22363 & 6,3 & 49936 & 14,1 & 355139 \\
\hline Grades 7-9 & 12711 & 7,2 & 15975 & 9,1 & 28686 & 16,3 & 175686 \\
\hline Further education & 35 & 5,1 & 164 & 24,0 & 199 & 29,1 & 683 \\
\hline Altogether & 40506 & 7,5 & 39420 & 7,3 & 79926 & 14,7 & 542932 \\
\hline Boys & 26444 & 9,5 & 27371 & 9,7 & 53815 & 19,3 & 278306 \\
\hline Girls & 14062 & 5,3 & 13049 & 4,6 & 26111 & 9,9 & 264626 \\
\hline
\end{tabular}

During the writing of this article, support in learning and school attendance is divided into general, intensified and special support. Official statistics indicate that after the 2010 law amendment, the number of pupils receiving intensified support has increased every year. In the fall of 2014, 40,506 comprehensive school pupils received intensified support; that is 7.5 percent of all pupils attending compulsory education (Table 1) showing an increase of 4.2 percent since 2011. (Statistics Finland: Special education 2014). In 2013, 65 percent of the pupils in intensified support were boys and 35 percent girls (Statistics Finland: Special education 2013). The amount of pupils receiving special support has therefore, been in a slight decline since 2011. Although from autumn 2014 to 
autumn 2013 enrolment rate has remained unchanged. In other words, the positive development, i.e., the decline in the number of pupils receiving special support since 2011 seems to have stopped (Heiskala, 2014). Notably, pupils receiving special support solely in mainstream education groups fell about 35 percent from 2010 to 2013 . According to Lintuvuori (2015), this is mainly due to changes in classification method. However, he also believes that past recipients of special support have been reallocated to intensified support.

Examination of special education and the development of inclusive ideology are complicated by the fact that the statistics describing special education in the Finnish comprehensive school now contain information mainly on intensified and special support. Information about pupils receiving general support is obtained by observing the number of pupils who have received special education on a part-time basis. Pupils are entitled to part-time special education in all levels of support. For example, in the academic year of 2013-2014, there were 122,891 Finnish pupils in part-time special education, a total of 120,200 pupils in 2012-2013, and 116,300 pupils in the year before that (2011-2012), which is, again, less than the previous year. Part-time special education has been on the increase despite the fact that the overall number of pupils in basic education has not changed (Statistics Finland: Special education, 2013; Special education, 2014.)

Furthermore, statistics from 2014 indicate that about 40 percent of all Finnish pupils in special education studied permanently in special groups within special schools or other similar facilities. The same amount of pupils studied at least half of the time in mainstream groups and 20 percent of special education pupils were entirely in general education (Statistics Finland: Special education 2014.) According to the statistics, the amount of pupils in mainstream education seems to have diminished in comparison to previous years (Statistics Finland: Special education 2013).

The classification of special needs pupils and the change in terminology in special education are particularly problematic from interpretive point of view (see for example, Farrell, 2001; Vehmas, 2010). Over the years, the fact that national titles have varied and the term "pupil with special needs" has been removed from official documents, does not make interpretation on the progress of inclusion ideology any easier. According to several researchers (e.g., Goodley, 2007; Liasidou, 2012; Niemi, 2014; Vehmas, 2010) this change has not improved the position of challenging pupils. Furthermore, changes in terminology that are based on the abnormal-normal division have not led to real changes in the school's informal divisions. Currently, the politically correct term "special needs" has not been clearly defined (Vehmas, 2010, p. 88) and therefore appears to be associated with a number of disabilities, conditions, disorders and difficulties (Niemi, 2014, p. 353). The practical consequence of all this is that, pupils who need special and intensified support may continue to be stigmatized by the term during their comprehensive school years and later in vocational education. Niemi $(2014$, p. 353) notes that the terms deleted from the official educational language (and also from the statistics), as well as the classifications and abbreviations based on medicalising discourse, still continue to exist in the Finnish schools and educational institutions. However, Vehmas (2010) points out that it is not absolutely certain that classification based on the level of the three-tier support should permanently be in juxtaposition with the realisation of social inclusion. Hale, van der Meer, Rutherford, Lynne, Janssen and Powell (2013, p. 151) indicates furthermore that it is very important to generate discussion about disability and identifies challenges to embed disability awareness into the curriculum and also among the university staff.

\section{Conclusions}

Based on recent research and existing statistics, it is possible to conclude that the reconstruction of abnormality has been a slow cultural process in this country. Yet, not as slow as merely interpreting the statistics would indicate. We can assume that there are other causes beyond those we have introduced in this article. For example, the transition from an agrarian society to an industrial society and further to a post-modern society happened late and in close succession. There are researchers (e.g., Aukee, 2013), who have witnessed a certain "hypersensitivity" to abnormality that has risen from the rapid social change and is, for that reason, still strongly a part of our current value system. When abnormality in Finland gradually transforms into post-modern "inclusive diversity", we will, assumedly, follow in the footsteps of Spain, Italy and Sweden, where the so-called one-track approach was adopted more than a decade ago. The dual system that was applied to basic education has practically disappeared in these countries. It has been replaced by the aspiration to take individual needs into account, i.e., bringing the individualised services into the general education class rooms (e.g., European Agency for Development in Special Needs Education, 2003).

The issues raised in this article show that analysing statistics is not only challenging but that they are also quite capable of distorting reality. When we take a look at the fluctuation in the number of pupils in special education during the last twenty years, it becomes apparent that other reasons, beyond an actual increase, are responsible; 
different statistical methodologies or changes in terminology for example. It can also be explained by changed norms, changed school systems, or social phenomena in general. Furthermore, statistics do not always reveal the real reason or need for the allocation of pupils to special education. In assessing inclusion development in the Finnish school system, it should be noted that after 2010, Statistics Finland completely abandoned the classification system they had been using thus far. This was caused by the fact that the number of migrant pupils had rapidly grown in the country, which meant that a redefinition of the main reasons for special education was in order; some felt it was an impossible task. Statistics can also be interpreted differently, i.e., rather than children and young people, the operational environment as well as attitudes towards difference have changed over the years. Many a Finnish child who in the 1970s would not have been entitled to special treatment would definitely be classified as "different" in the school of the new millennium. Especially, pupils who have behavioural, motivational and concentration issues are pupils whose classification into special education pupils, according to Jahnukainen (2003), is dependent on the school's and teachers' attitudes towards tolerance and diversity (including Jahnukainen, 2003, pp. 503-504).

Likewise, there have been changes in the norms and regulations in school practices. Finnish comprehensive school had high expectations for the 2010 Basic Education Act and the so-called three-tier support model. However, it seems that from inclusion policy point of view the three-tier model did not work entirely as expected. An argument can be made on the grounds that the amount of pupils who need special education has fallen as little as 0.8 percentage since 2011 while the overall number of pupils has stayed the same. Similarly, the amount of pupils who need special support but attend mainstream education has remained unchanged. The three-tier system was believed to make special education transfers part-time and flexible and thus improve pupils' status in the school community. It was also believed to lessen and even prevent marginalisation in the school and later in society (Niemi, 2014, p. 351). Nonetheless, perhaps the increase in part-time special education is not a completely negative development. It could also be a sign of the effectivity of the three-tier model-i.e., pupils who need it receive timely and sufficient support. Instead, the increase in special and even intensified support can possibly be explained by special education transfers. There are also weak signs that indicate that transfers within a school are a possibility: pupils receiving intensified support can be transferred fully or mostly to a special group (e.g., Pulkkinen \& Jahnukainen, 2015 , p. 103). However, in making this interpretation it's good to remember that the establishment of the three-tiered support system has reinforced the importance of pedagogical expertise as transfers to special education do not currently require a medical diagnosis in Finland.

And how has the changed economic situation affected the inclusion policy? How do we interpret, the current lack of resources in many Finnish municipalities, due to which special support pupils have been proven to have been placed in mainstream education groups without adequate support measures? The Act on Central Government Transfers to Local Government for Basic Public Services (1704/2009) came into force in Finland at the beginning of 2010. According to the new act Finnish municipalities no longer receive personal and increased state aid for special education transfers; it now merely covers pupils in extended compulsory education. A few years back, the increase in the number of pupils transferred to special education could partly be explained by the state aid - it attracted transfers and even false claims. According to Saloviita (2006), increased state aid could be paid in such transfers where the child was not actually transferred to special education, but remained full-time in his/her former class. Statistics understand such pupils to be "fully integrated". In this article we are in agreement with Pulkkinen and Jahnukainen (2015, p. 80) among others, according to whom the increased state aid encouraged municipalities to classify pupils accordingly. Each transfer that was open to interpretation was reflected in the statistics and thus complicates the objective assessment of inclusion development.

\subsection{Change in Operating Culture Leads to Change in Thinking}

How, then, to develop a school system that encourages participation and learning in every pupil as effectively as possible? Is it possible to estimate the degree of advancement in inclusive pedagogy in the statistics? Will the issue of increased special education be solved by regulating the number of pupils with special needs? Our response to the last two questions is "no" as the transformation is considerably more profound and permeates school's operational culture much more thoroughly. In any case, the school does not -in Finland, and we believe anywhere else- turn inclusive due to an administrative decision, nor because of individual teachers and their efforts. The progress towards an inclusive school is dependent on the school's pedagogic director, and in particular his or her leadership skills (e.g., Katz \& Sugden, 2013). Essentially, a holistic management culture plays a key role in the development of the whole community (also Ahtiainen, 2015). Many recent studies show that school management in particular, must be strongly committed to inclusive values (e.g., Dyson, 2010; Mitchell, 2008). 
Moreover, recent studies and statements indicate that the promotion of inclusive school culture is based, not only on school management's and teacher's individual attitudes and skills, but on the whole school community and its ability to generate, support and guide the co-operative processes. In practice, development skills are essential to that process (e.g., Booth \& Ainscow, 2002; European Agency for Development in Special Needs Education, 2012; Isosomppi \& Leivo, 2015), they lead to genuinely inclusive schools transmitting the inclusive viewpoint by principle of penetrability; such schools are also skilled in using the available evaluation tools for assessing involvement (Isosomppi \& Leivo, 2015). For the development of the school, it is essential that teachers commit to advancing inclusiveness and recognize and oppose segregating practices (also Ainscow, Dyson, \& Weiner, 2014). The collaboration amongst teachers is necessary, when developing inclusive schoolculture (Katz \& Sugden, 2013). We must remember that it is every pupil's fundamental right to be a full member in the community. According to Saarinen, Jahnukainen and Pirttimaa (2016, p. 314), it is very important that every child have friendships, contacts with others and particularly can participate in the construction of communities and roles.

Attitudes have the seeds for change. Several international research projects show that teachers who have experience in teaching pupils with special needs, have a more positive attitude toward inclusivity and teaching a wide range of children in one group compared to teachers who have little or no experience in it (e.g., Avramidis \& Kalyva, 2007; Isosomppi \& Leivo, 2015; McMaster, 2014). Indeed, the European Agency for Development in Special Needs Education (European Agency for Development in Special Needs Education, 2012) has devised a profile for "an inclusive teacher" that establishes the values and skills that are a part of every inclusive teacher's professional competence (European Agency for Development in Special Needs Education 2012, pp. 20-21). These characteristics comprise of valuing learner diversity, supporting all learners, working with others and personal professional development. We agree with those researchers (e.g., Ainscow, Dyson, \& Weiner, 2014; Eskelä-Haapanen, 2011; Takala, 2010), who state that all teachers should have an internalised notion of what an inclusive school is but also an awareness of learner diversity.

How is inclusive competence in teachers strengthened? Researchers have highlighted the need for authentic experience in authentic learning environments (i.e., schools) and the communal reflection of these experiences as well as connecting that knowledge to inclusive education's theoretical premises (Heikkinen, Jokinen, \& Tynjälä, 2012; Isosomppi \& Leivo, 2015; Waitoller \& Kozleski, 2013). It has been hoped that there would be more continuing education that would encourage cooperation between special education teachers and other teachers. In Finland, Mietola and Niemi (2014) have found that the lack of interaction between ordinary and special education maintain difference and otherness. The Finnish school culture still shows signs of the dual system where special education has, for decades, enclosed pupils within separate institutions and thus the connection to mainstream education has been severed. Despite the fact that pedagogical practises that promote inclusion (simultaneous teaching, joint teaching, open learning environments and other flexible educational arrangements) have been furthered in formal speeches, formal education and manuals, progress in the school level has been slow. Messages coming from the Finnish schools still indicate how special education teachers and mainstream teachers, who have worked in the same school for years, have not visited each other's classes and cooperation is mainly linked to special occasions and school functions.

Making accusations is not part of the inclusive school development toolkit. We view the situation as Ainscow, Dyson and Weiner (2014) have, that is, we see the school as a cultural and social space providing insufficient time and opportunities for teachers to re-structure their own work. We also share McMaster's (2014) definition, according to which change that promotes inclusion takes place when exposing and sharing values that are deeply rooted in the society, especially those that define the relationship between a teacher and a pupil. In order for that to be possible, teachers should have more opportunities to observe and follow their colleagues at work. Through shared experience, colleagues can help one another describe their actions and ponder their contribution to the development of inclusiveness in their own schools. In practice, a change in school culture requires, under the school leadership, a critical examination and assessment of joint activities in order for exclusionary practises to slowly be revealed and left behind. The stronger the intellectual and emotional engagement to education, the deeper engagement to justice, equality and inclusion (Mäkinen, 2013).

Finally, in assessing the progress of inclusive thinking, it must be remembered that inclusion has, for decades, divided the opinions of experts everywhere (Rowan, 2009, p. 146), and will continue to do so in the future. In our view, inclusion critique, echoing Vehmas (2009), has been connected to the tensions between different definitions of disability (individual, psycho-medical vs. social description) as well as to the existing preconditions for inclusion (e.g., Mitchell, 2008). We understand the critics. Unless Mitchell's (2008) "magic formula", i.e., the central prerequisites and conditions for inclusion exist (e.g., common vision, investment, support, resources, pedagogical leadership, being involved in local community, individual curriculum plans and individual 
educational arrangements and community approval), inclusion cannot be accountable and effective and thus the weaknesses have greater prominence. If adequate support is not available, teaching all pupils in the same educational environment can be detrimental or ever irresponsible. There are also those (and not just in Finland) who long for the reintroduction of the dual system (see Meijer, 2010). According to them, when organising education, we should not merely emphasise location but the fact that pupils should have the opportunity to receive the best possible education for individual growth and learning.

\section{References}

Ahtiainen, R. (2015). Oppimisen ja koulunkäynnin tuen muutos reformina. In M. Jahnukainen, E. Kontu, H. Thuneberg, \& M.-P. Vainikainen (Eds.), Erityisopetuksesta oppimisen ja koulunkäynnin tukeen (pp. 25-42). Finnish Educational Research Association, Research in Educational Science.

Ainscow, M., \& César, M. (2006). Inclusive education ten years after Salamanca: Setting the agenda. European Journal of Psychology of Education, 21(3), 231-238. https://doi.org/10.1007/BF03173412

Ainscow, M., Dyson, A., \& Weiner, S. (2014). From Exclusion to Inclusion. A review of international literature on ways of responding to pupils with special educational needs in schools. Retrieved from http://rabida.uhu.es/dspace/bitstream/handle/10272/8169/De_la_exclusion_a_la_inclusion.pdf?sequence=2

Aukee, R. (2013). Vanhasta uuteen sosiaalilääketieteeseen. Suomalaisen sosiaalilääketieteen muotoutuminen 1800-luvun lopulta vuosituhannen vaihteeseen. Tampere: Acta Universitatis Tamperensis 1825.

Avramidis, E., \& Kalyva, E. (2007). The influence of teaching experience and professional development on Greek teachers' attitudes towards inclusion. European Journal of Special Needs Education, 22(4), 367-389. https://doi.org/10.1080/08856250701649989

Booth, T., \& Ainscow, M. (2002). Index for inclusion, developing learning and participation in schools. Bristol, UK: Centre for Studies on Inclusive education (CSIE).

Eskelä-Haapanen, S. (2012). Kohdennettu tuki perusopetuksen alkuluokilla (Doctoral dissertation). University of Tampere, Acta Universitatis Tamperensis 1747. Retrieved from http://tampub.uta.fi/bitstream/handle/10024/66922/978-951-44-8849-8.pdf

European Agency for Development in Special Needs Education. (2003). Erityisopetus Euroopassa. Retrieved from https://www.european-agency.org/

European Agency for Development in Special Needs Education. (2012). Profile of Inclusive Teachers. Odense, Denmark: European Agency for Development in Special needs education. Retrived from https://www.european-agency.org/sites/default/files/Profile-of-Inclusive-Teachers.pdf

Farrel, P. (2001). Special education in the last twenty years: Have things really got better? British Journal of Special Education, 28(1), 1-9.

Finnish National Board of Education. (2004). Basic Education Act 2004. Helsinki: Finnish National Board of Education.

Finnish National Board of Education. (2011). Amendments and supplements to Basic Education Act 2010. Regulations and Guidelines 20, Helsinki: Finnish National Board of Education.

Finnish National Board of Education. (2014). Basic Education Act 2014. Regulations and Guidelines 96, Helsinki: Finnish National Board of Education.

Goodley, D. (2007). Towards socially just pedagogies: Deleuzoguattrian critical disability studies. International Journal of Inclusive Education, 11(3), 317-334. https://doi.org/10.1080/13603110701238769

Hale, L., van der Meer, J., Rutherford, G., Clay, L., Janssen, J., \& Powell, D. (2013). Exploring the Integration of Disability Awareness into Tertiary Teaching and Learning Activities. Journal of Education and Learning, 2(1), 147-157. https://doi.org/10.5539/jel.v2n1p147

Hautamäki, J., \& Hilasvuori, T. (2015). Perusopetuslain erityisopetusta koskevat vuoden 2010 muutokset viimeisimpänä vaiheena peruskoulun kehitystä. In M. Jahnukainen, E. Kontu, H. Thuneberg, \& M.-P. Vainikainen (Eds.), Erityisopetuksesta oppimisen ja koulunkäynnin tukeen (pp. 15-24). Finnish Educational Research Association, Research in Educational Sciences 67.

Heikkinen, H. L. T., Jokinen, H., \& Tynjälä, P. (2012). Teacher education and development as lifelong and lifewide learning. In H. L. T. Heikkine, \& P. Tynjälä (Eds.), Peer-Group Mentoring for Teacher Development (pp. 3-30). Milton Park: Routledge. 
Heiskala, T. (2014). Joka neljäs peruskoululainen saa tukea oppimiseensa. Hyvinvointikatsaus 3, Helsinki: Tilastokeskus. Retrieved from http://tilastokeskus.fi/artikkelit/2014/art_2014-09-29_005.html

Helakorpi, J., Mietola, R., \& Niemi, A.-M. (2014). Tasa-arvoisten mahdollisuuksien vuoksi erillään? Erityisluokkien oppilaat koulun sosiaalisissa ja institutionaalisissa järjestyksissä. In M. Gissler, M. Kekkonen, P. Känkänen, P. Muranen, \& M. Wrede-Jäntti (Eds.), Nuoruus toisin sanoen. Nuorten elinolot-vuosikirja (pp. 161-173). Tampere: Terveyden ja hyvinvoinnin laitos.

Isosomppi, L., \& Leivo, M. (2015). Becoming an inclusive teacher at the interface of school and teacher education. Procedia Social and Behavioral Sciences, 171, 686-694. https://doi.org/10.1016/j.sbspro.2015.01.178

Jahnukainen, M. (2003). Laman lapset? Peruskoulussa erityisopetusta saaneiden oppilaiden osuuksien tarkastelua vuodesta 1987 vuoteen 2001. Yhteiskuntapolitiikka, 68(5), 501-507.

Jahnukainen, M. (2015). Johdanto. In M. Jahnukainen, E. Kontu, H. Thuneberg, \& M.-P. Vainikainen (Eds.), Erityisopetuksesta oppimisen ja koulunkäynnin tukeen (pp. 7-11). Finnish Educational Research Association, Research in Educational Sciences 67.

Järvinen, T., \& Jahnukainen, M. (2008). Koulutus, polarisaatio ja tasa-arvo: Hyvä-ja huono-osaistuminen perus-ja keskiasteen koulutuksessa. In M. Autio, K. Eräranta, \& S. Myllyniemi (Eds.), Polarisoituva nuoruus. Nuorten elinolot-vuosikirja (pp. 140-149). Nuorisotutkimusverkoston julkaisuja 84, Nuorisoasiain neuvottelukunnan julkaisuja 38, Helsinki: Sosiaali-ja terveysalan tutkimuskeskus.

Katz, J., \& Sugden, R. (2013). The three-block model of universal design for learning implementation in a high school. Canadian Journal of Educational Administration and Policy, 141.

Kivirauma, J. (2001). Erityisopetuksen historialliset kehityslinjat Suomessa. In M. Jahnukainen (Ed.), Lasten erityishuolto ja-opetus Suomessa (11th ed., pp. 23-33). Helsinki: Lastensuojelun Keskusliitto.

Kivirauma, J. (2015). Erityispedagogiikka tieteenä. In S. Moberg, J. Hautamäki, J. Kivirauma, U. Lahtinen, H. Savolainen, \& S. Vehmas (Eds.), Erityispedagogiikan perusteet (pp. 11-23). Jyväskylä: PS-kustannus.

Koulutus ja tutkimus vuosina 2007-2012. (2007-2012). Kehittämissuunnitelma. Education and Research 2007-2012. Development Plan. Opetusministeriön työryhmämuistioita ja selvityksiä 2007: 26. Helsinki: Ministry of Education and Culture.

Koulutus ja tutkimus vuosina 2011-2016. (2011-2016). Kehittämissuunnitelma. Education and Research 2007-2012. Development Plan. Opetus-ja kulttuuriministeriön julkaisuja 2012:1. Helsinki: Ministry of Education and Culture.

Ladonlahti, T., \& Naukkarinen, A. (2006). Osallistava kasvatus ja opettajankoulutuksen haasteet. Kasvatus, 37(4), 343-358.

Laki kunnan peruspalvelujen valtionosuudesta 2009. (2009).

Laki perusopetuslain muuttamisesta 2010. (2010).

Liasidou, A. (2012). Inclusive education and critical pedagogy at the intersections of disability, race, gender and class. Journal for Critical Education Policy Studies, 10(1), 168-184.

Lintuvuori, M. (2015). Oppimisen ja koulunkäynnin tuen järjestäminen virallisen tilastotiedon ja empiirisen tutkimusaineiston kuvaamana. In M. Jahnukainen, E. Kontu, H. Thuneberg, \& M.-P. Vainikainen (Eds.), Erityisopetuksesta oppimisen ja koulunkäynnin tukeen (pp. 43-76). Finnish Educational Research Association, Research in Educational Sciences 67.

Malinen, O.-P., Savolainen, H., Engelbrecht, P., \& Xu, J. (2009). Inklusiivisen opetuksen kansainvälinen ja vertaileva tutkimus. Kasvatus, 41(4), 351-362.

McMaster, C. (2014). Elements of inclusion: Findings from the Field. Kairaranga, 15(1), 42-49. Retrieved from http://files.eric.ed.gov/fulltext/EJ1040134.pdf

Meijer, C. J. W. (2010). Special Needs Education in Europe. Inclusive policies and practices. Retrieved from $\mathrm{http}: / / w w w . i n k l u s i o n-o n l i n e . n e t / i n d e x . p h p /$ inklusion-online/article/view/136/136

Mietola, R. (2014). Hankala erityisyys. Etnografinen tutkimus erityisopetuksen käytännöistä ja erityisyyden muotoutumisesta yläkoulun arjessa (Doctoral dissertation). University of Helsinki, Research in Educational Sciences 255. Retrieve from http://urn.fi/URN:ISBN:978-952-10-9375-3 
Mietola, R., \& Niemi, A.-M. (2014). Erityisopetus ja koulutuksellisen inkluusion toteutuminen. In S. Pulkkinen, \& J. Roihuvuori (Eds.), Erkanevat koulutuspolut-Koulutuksen tasa-arvon tila 2010-luvulla (pp. 66-83). Suomen ylioppilaskuntien liitto (SYL) ry.

Ministry of Education and Culture. (2007). Strategy of Special Needs. In Committee Records and Reports of Ministry of Education and Culture (Vol. 47). Helsinki: Ministry of Education and Culture.

Mitchell, D. (2008). What really works in Special and Inclusive Education. Using evidence-based teaching strategies. London: Routledge.

Moberg, S., \& Savolainen, H. (2015). Yhteistä koulua kohti. In S. Moberg, J. Hautamäki, J. Kivirauma, U. Lahtinen, H. Savolainen, \& S. Vehmas (Eds.), Erityispedagogiikan perusteet (pp. 75-102). Jyväskylä: PS-kustannus.

Mäkinen, M. (2013). Becoming engaged in inclusive practices: Narrative reflections on teaching as descriptors of teachers' work engagement. Teaching and Teacher Education, 35, 51-61. https://doi.org/10.1016/j.tate.2013.05.005

Naukkarinen, A. (2000). Konstruktionistisen näkökulman merkitys inklusiivisen koulun rakentamisessa. Kasvatus, $31(12), 159-170$.

Niemi, A.-M. (2014). Tuki, tarve, leima, oikeus? Erityisyyden muotoutuminen ammatillisen koulutuksen diskursseissa. Kasvatus, 45(4), 349-363.

Oppilas-ja opiskelijahuoltolaki. (2013).

Pihlaja, P. (2009). Erityisen tuen käytännöt varhaiskasvatuksessa. Kasvatus, 49(2), 146-157.

Pulkkinen, J., \& Jahnukainen, M. (2015). Erityisopetuksen järjestäminen ja resurssit kunnissa lakimuutoksen jälkeen. In M. Jahnukainen, E. Kontu, H. Thuneberg, \& M.-P. Vainikainen (Eds.), Erityisopetuksesta oppimisen ja koulunkäynnin tukeen (pp. 79-105). Finnish Educational Research Association, Research in Educational Sciences 67.

Saari, A. (2011). Inkluusion nosteet ja esteet liikuntakulttuurissa. Tavoitteena kaikille avoin liikunnallinen iltapäivätoiminta (Doctoral dissertation). University of Jyväskylä, Studies in Sport, Physical Education and Health 174. Retrieved from http://urn.fi/URN:ISBN:978-951-39-4433-9

Saarinen, M. K., Jahnukainen, M. T., \& Pirttimaa, R. A. (2016). The Social Networks of People with Intellectual Disabilities during the On-Campus Supported Adult Education Programme. Journal of Education and Learning, 5(2), 302-317. https://doi.org/10.5539/jel.v5n2p302

Salminen, J., \& Annevirta, T. (2014). Opetussuunnitelman perusteiden välittämä ohjaus-mitä, kelle ja miksi? Kasvatus, 45(4), 333-348.

Saloviita, T. (2006). Erityisopetus ja inkluusio. Kasvatus, 37(4), 326-342.

Saloviita, T. (2012). Inkluusio eli “osallistava kasvatus”. Lähteitä sekä 13 perustetta inkluusiota vastaan. Retrieved from http://users.jyu.fi/ saloviit/tutkimus/inclusion.html

Seppälä-Pänkäläinen, T. (2009). Oppijoiden moninaisuuden kohtaaminen suomalaisessa lähikoulussa. Etnografia kouluyhteisön aikuisten yhdessä oppimisen haasteista ja mahdollisuuksista (Doctoral dissertation). University of Jyväskylä, Jyväskylä Studies in Education, Psychology and Social Research 364.

Suomen virallinen tilasto. Erityisopetus. (2010). Helsinki: Tilastokeskus. Retrieved from http://www.stat.fi/til/erop/2010/erop_2010_2011-06-09_tie_001_fi.html

Suomen virallinen tilasto. Erityisopetus. (2013). Liitetaulukko 8.Osa-aikaista erityisopetusta saaneet peruskoulun oppilaat lukuvuodesta 2001-2002 lukuvuoteen 2012-2013. Helsinki: Tilastokeskus. Retrieved from http://www.stat.fi/til/erop/2013/erop_2013_2014-06-12_tau_008_fi.html

Suomen virallinen tilasto. Erityisopetus. (2014). Liitetaulukko 3. Tehostettua tukea saaneet peruskoulun oppilaat 2011-2014. Helsinki: Tilastokeskus. Retrieved from http://www.stat.fi/til/erop/2014/erop_2014_2015-06-11_tau_003_fi.html

Suomen virallinen tilasto. Erityisopetus. (2014). Liitetaulukko 5. Erityistä tukea saaneet peruskoulun oppilaat opetuksen toteutuspaikan mukaan. Helsinki: Tilastokeskus. Retrieved from http://www.stat.fi/til/erop/2014/erop_2014_2015-06-11_tau_005_fi.html 
Suomen virallinen tilasto. Erityisopetus. (2014). Liitetaulukko 8. Osa-aikaista erityisopetusta saaneet peruskoulun oppilaat lukuvuodesta 2001-2002 lukuvuoteen 2012-2013. Helsinki: Tilastokeskus. Retrieved from http://www.stat.fi/til/erop/2014/erop_2014_2015-06-11_tau_008_fi.html

Takala, M. (2010). Erityispedagogiikka ja kouluikä. Helsinki: Gaudeamus.

Thuneberg, H., \& Vainikainen, M.-P. (2015). Uuden lain toteutuminen pedagogisten dokumenttien perusteella. In M. Jahnukainen, E. Kontu, H. Thuneberg, \& M.-P. Vainikainen (Eds.), Erityisopetuksesta oppimisen ja koulunkäynnin tukeen (pp. 135-162). Finnish Educational Research Association, Research in Educational Sciences 67.

UN. (2014). Convention on the rights of persons with disabilities. Retrieved from http://www.un.org/disabilities/convention/conventionfull.shtml

UNESCO. (1994). The Salamanca statement and framework for action on special needs education. Salamanca: UNESCO, Ministry of education and Science. Retrieved from http://unesdoc.unesco.org/images/0009/000984/098427eo.pdf

Waitoller, F. R., \& Artiles, A. J. (2013). A Decade of Professional Development Research for Inclusive Education: A Critical Review and Notes for a Research Program. Review of Educational Research, 83(3), 319-356. https://doi.org/10.3102/0034654313483905

Waitoller, F. R., \& Kozleski, E. B. (2013). Working in boundary practices: Identity development and learning in partnerships for inclusive education. Teaching and Teacher Education, 31, 35-45. https://doi.org/10.1016/j.tate.2012.11.006

Vehmas, S. (2010). Special needs: A philosophical analysis. International Journal of Inclusive Education, 14(1), 87-96. https://doi.org/10.1080/13603110802504143

Viitala, R. (2004). Ideologisia ja pedagogisia lähtökohtia erityistä tukea tarvitsevien lasten kanssa toimittaessa. In R. Viitala, \& P. Pihlaja (Eds.), Erityiskasvatus varhaislapsuudessa (pp. 131-152). Helsinki: WSOY.

\section{Copyrights}

Copyright for this article is retained by the author(s), with first publication rights granted to the journal.

This is an open-access article distributed under the terms and conditions of the Creative Commons Attribution license (http://creativecommons.org/licenses/by/4.0/). 